26. Havránek A. Pruzne kyvadlo - vysetrovani bifurkace metodami newtonovske mechaniky. URL: https://web.vscht.cz/pokornp/h/ PrzkvHerb2.doc

27. Dvořák L. Pružné kyvadlo: od teoretické mechaniky k pokusům a zase zpátky // Pokroky matematiky, fyziky a astronomie. 2006. Vol. 51, Issue 4. P. 312-327.

28. Havránek A., Čertík O. Pružné kyvadlo // Pokroky matematiky, fyziky a astronomie. 2006. Vol. 51, Issue 3. P. $198-216$.

29. Kutsenko L. M., Piksasov M. M., Zapolskyi L. L. Iliustratsiyi do statti «Heometrychne modeliuvannia periodychnoi traiektoriyi vantazhu khytnoi pruzhyny». 2018. URL: http://repositsc.nuczu.edu.ua/handle/123456789/7637

30. Kutsenko L. M., Piksasov M. M., Vasyliev S. V. Iliustratsiyi do statti «Klasyfikatsiya elementiv simi periodychnykh traiektoriy rukhu vantazhu khytnoi pruzhyny». 2019. URL: http://repositsc.nuczu.edu.ua/handle/123456789/8658

31. Kutsenko L. M., Piksasov M. M., Shevchenko S. M. Iliustratsiyi do statti «Modeliuvannia rezonansu khytnoi pruzhyny na osnovi syntezu traiektoriyi rukhu yii vantazhu». 2019. URL: http://repositsc.nuczu.edu.ua/handle/123456789/8950

32. Kalinichenko V. A., Aung Naing So A. N. S. Faraday waves in a movable tank and their mechanical analog // Engineering Journal: Science and Innovation. 2013. Issue 12. doi: https://doi.org/10.18698/2308-6033-2013-12-1138

Барабанні змімувачі можуть забезпечити заданий рівень рівномірності змішування, в тому числі компонентів кормових добавок. Однак питання теоретичного та експериментального обтрунтування конструкційно-кінематичних параметрів барабанних змішувачів недостатньо науково досліджене. Метою роботи є підвищення ефективності виробництва кормових сумішей иляхом забезпечення оптимальної кутової ивидкості обертання барабанного змінувача.

Для визначення радіальної ивидкості руху частки по лопатці барабана був використаний розв'язок однорідного диференційного рівняння. Визначення числового значення кутової швидкості реалізовано методом комп'ютерного моделювання. Проведення експериментальних досліджень рівномірності перерозподілу кормових компонентів у суміші комбікорму здійснювалося за допомогою розробленого експериментального барабанного зміиувача. Змішувач складався з камери, прямокутної рамки, опорної рами та приводу. Камера змішування мала завантажувально-розвантажувальне вікно закрите кришкою. Всередині камери по всій ї̈ довжині і рівномірно по периметру були встановленої радіальні лопатки.

Досліди проводилися із використанням барабанного змішувача із радіусом барабана 0,17м, який мав радіальні лопатки шириною 25 мм та при коефічієнті заповнення камери 0,5. Встановлено, що барабанний змінувач забезпечує максимальне розсіювання часточок матеріалу по поверхні робочого сегменту при кутовій ивидкості обертання барабану 9,69 рад/с.

У результаті експериментальних досліджень встановлено, що при частоті обертання барабана лабораторної установки 9,42 рад/с рівномірність сумішки становить 92,5-93\%, що відповідає існуючим зоотехнічним вимогам для всіх видів комбікормів. При цьому максимальне відхилення теоретичних та експериментальних даних становило біля $9 \%$. Отримані результати дають змогу стверджувати про можливість визначення числового значення кутової ивидкості барабанних змішувачів запропонованим методом комп'ютерного моделювання

Ключові слова: лопатка, радіальна ивидкість, коефічієнт заповнення, час змішування, кормові добавки, контрольний компонент, суміш, радіус барабана

$\square$
UDC 621.929.6:636.085.55

DOI: $10.15587 / 1729-4061.2019 .166944$

OPTIMIZATION OF ANGULAR VELOCITY OF DRUM MIXERS

G. Golu b

Doctor of Technical Sciences, Professor, Head of Department* E-mail: gagolub@ukr.net Y. My hailov y c h $\mathrm{PhD}$, Professor

Department of Technical Service and Engineering Management named after Mykola Momotenko** E-mail: yaroslav_m@ukr.net

O. A c h k e v y c h

$\mathrm{PhD}$, Associate Professor

Department of Lifestock Mechanization** E-mail: achkevych@gmail.ru V. Ch u b a

$\mathrm{PhD}$, Associate Professor*

E-mail: vvchuba@ukr.net

*Department of Tractors, Automobiles and Bioenergy System** **National University of Life and Environmental Sciences of Ukraine

Heroiv Oborony str., 15, Kyiv, Ukraine, 03041

\section{Introduction}

Among animal feed, a leading role belongs to mixed fodder, which is a concentrated source of nutrients and a means to balance rations in accordance with standards of animal nutrition. Over recent time, production of mixed fodder is moved from specialized mixed fodder factories directly to agricultural manufacturing. Engineers designed and produced a significant number of mixed fodder units whose operation is based on using own grain raw materials and the commercially 
available protein-mineral-vitamin mixtures. In this case, the cost of mixed fodder manufactured directly at farms is 15-25\% lower than that from specialized enterprises [1].

Feed additives are added to the grain components of the ration. Introducing them makes it possible to balance feed rations in terms of nutrients that are necessary for animals, the need for which is low compared to the basic types of feeds. That creates certain difficulties when distributing them evenly in feed mass. The quality of a feed mixture depends on the uniformity of distribution of feed additives in a mixture. The better the feed components are mixed, the greater the probability that all animals receive the required amount of nutrients and stimulating substances. The lack of equipment for mixing feed additives under conditions of farms prevents obtaining high-quality mixed fodder.

The concentration of protein-vitamin supplements and micro-components that are included in the composition of mixed fodder may differ from the content of the basic component by one or two orders of magnitude. Given the difference in the ratio of components in mixed fodder, there is a need to apply mixing in stages, starting with components that have the least concentration with a transition at the subsequent stage to mixing the components with the greatest concentration. Based on these conditions, the farm-based mixed fodder plants must be supplemented with stirrers that would make it possible to ensure the mixing of components in stages. In this regard, it is required to improve the mechanized technology for stagewise mixing of components in mixed fodder and to substantiate the structural-technological parameters for mixers, which could make it possible to produce mixed fodder with a high uniformity in component distribution.

\section{Literature review and problem statement}

The drum mixers that are used for mixed fodder production are also applied in food, cosmetic, pharmaceutical, chemical, flour milling, and other industries. Drum mixers are designed for mixing solid, granular, powdery, granulated substances with different specific weight. Drum mixers are used to prepare powder mixtures, as well as to mix granular, abrasive, explosive materials in cases where it is necessary to provide for a high uniformity of the resulting mixture. Drum mixers demonstrate high performance by preparing a high-quality homogenous mixture over a short time and at low maintenance costs. Their advantages include: the preservation of the materials properties, minimal energy consumption, simple installation and maintenance, a low noise level during operation and the absence of «dead» zones at stirring.

In addition to mixing, drum mixers are also applied for carrying out the process of granulation, emulsifying, drying, roasting, saturation with liquid components $[2,3]$.

The principle of operation of drum mixers implies stirring a starting material by the drum rotation and the action of blades mounted inside it. In this case, by using the blades a product rises at drum rotation for a specific height relative to the bottom of the drum, and then it falls down upon reaching a certain angle; the effect of stirring occurs. The shaft around which a drum rotates may coincide with the axis of symmetry of the drum or with its diagonal. The drum itself may be of a different shape depending on the purpose and character of the mixed loose product.

Blades of various shapes are often installed inside a drum, which greatly improves the uniformity of a mixture [4]. The blades provide for a better distribution of a material within the free space of the drum, thereby making it possible to improve the uniformity of distribution of a mixture's components.

It is rather difficult to describe the process of mixing inside a drum mixer because it consists of a sequence of individual processes that stir a material in the chamber. To simplify the task, it is advisable to divide the cycle of rotation into separate phases and to consider the state of mixing at critical points.

Addressing the issue about the description of work of the drum-type machines employs both traditional and new theoretical and experimental research methods. There have been many attempts to solve numerically the problem on determining the operational parameters for a rotary chamber. This often involves a discrete element method (DEM). DEM-based modeling implies assigning a specific position and initial speed to all particles. Next, the forces influencing each particle are calculated based on the source data and relevant physical laws.

In [5], authors analyzed the results from applying the methods of DEM analysis to simulate the motion of particles of a non-spherical shape. It was established that the non-spherical particles typically demonstrate a lower loosening ability or stronger bonds than the sphere. One of the most important visualizations of this effect is a significant increase in the angle of inclination of non-spherical particles in a drum mixer. The methods reported by the authors make it possible to model the behavior of a multi-component environment based on analysis of the characteristics of geometric shapes and indicators for a contact interaction between components. The proposed methods allow the simulation of the effect of displacement, vibration, rotation on the internal processes in a multi-component mixture, but do not make it possible to define the optimal modes of operation and the structural parameters for mixing equipment.

Paper [6] used DEM to determine the influence of chamber rotation speed, the degree of filling a chamber with wet particles, and their adhesion, on a material's motion modes. It was noted that mixing over time, which is characterized by a Lacey index, can be described by an error function. The authors have also devised a theoretical model for predicting the efficiency of mixing. The results that the authors obtained are suitable for the simulation of mixing in a cylinder with a smooth inner surface, as well as components that are in the same proportion and possess similar properties and shapes.

Study [7] examined the influence of a shape of non-spherical particles on the distribution of a material's motion velocities in a rotating chamber with smooth walls. It was established that the transition from a regime of rolling to the cascade mode depends not only on a Froude number, the degree of filling and the size of particles, but on the shape of particles as well. The results obtained are based on the physical phenomenon of increased centrifugal forces resulting from an increase in the speed of chamber rotation. Consequently, there is an increase in rolling angle that leads to the cascading mode of a mixture's movement. The reported results make it possible to model the optimal rotation mode of drum mixers with a smooth surface, depending on the properties of materials in order to provide for the optimum circulation of a mixture in a mixer.

To study the influence of a particle's shape and the roughness of face walls in short chambers, paper [8] also applied DEM. It was found that for short drum mixers the area of contact between end walls relative to the side walls has a greater impact on mixing. Contact interaction between the components and end side surfaces counteracts the motion of particles, which, consequently, worsens the distribution of 
components in low-mobility regions. An extended mixing chamber weakens the effect of friction against the end walls. The authors paid attention to finding the optimal ratio for the dimensions of components that are mixed and the rotation speed of a drum mixer, but they failed to establish the optimal ration of end surfaces to the length of the drum.

Study [9] examined the mode under which a material pours over while a rotary chamber is filled with ellipsoid-shaped particles by using the advanced variant of DEM. At high rotation speed the ellipsoid-shaped particles, whose shape is closer to spherical, demonstrate a higher quality of mixing. The degree of mixing the elongated ellipsoidal particles is slightly higher than that for flattened ellipsoidal particles. It was also found that the high speed of drum rotation inhibits the axial dispersion, and the ratio of sides has no apparent influence on the axial dispersion. The data that the authors obtained from theoretical and experimental studies show a rather high convergence. However, they investigated and reported results only for mixing particles of similar shape that have the same proportion in a mixture. Typically, in the manufacture of mixed fodder, the basic component is supplemented with components whose concentrations in the mixture are significantly lower compared with the content of the basic component. In addition, a basic component in mixed fodder may significantly differ in shape and properties from the components that are added to the basic component.

To study the distribution of polygonal particles in a rotating chamber, work [10] applied DEM and the model of embedded deformed solid spherical particles. The process of mixing, the quality, speed, as well as kinetic energy, were defined by using an index of mixing and entropy. The authors established a significant increase in the mixing index of a material for particles of square, hexagonal, and triangular shape at rotation speed $\omega=7.85 \mathrm{rad} / \mathrm{s}$. The results were obtained for mixtures of specific density approximately $2,000 \mathrm{~kg} / \mathrm{m}^{3}$ and when mixing such components of a mixture whose volume was identical, which almost never happens in the production of mixed fodder.

DEM-based modeling that employed graphic processors was used to determine the influence of particles size on the distribution of motion velocities of particles in a slowly rotating chamber [11]. It was established that at a constant Froude number the ratio of particles size to the dimensions of a drum plays a dominant role in determining the distribution of velocity fields of materials at mixing. In addition, the authors observed that the Young modulus and a friction coefficient exert a greater impact on velocity fields than other properties of materials. The results obtained are characteristic of the mixers that mix the materials under a mode of materials rolling. The presence of regions with a rather low speed under a given mixing mode testifies to the significant time costs to obtain a homogeneous mixture.

A method of discrete elements that was devised for systems with an arbitrary geometry by using graphic processors was described in [12]. It was demonstrated that the graphic processing devices, designed in that work based on DEM, make it possible to simulate actual industrial processes. The work reported modeling of the influence of components' surface shape on the effective indicators for mixing, however, the authors did not fully consider the mass and ratio of components.

The movement of a material in rotary chambers was also investigated by using other methods, alternative to DEM, applying numerical algorithms. To study the parameters of work of drum mixers, [13] used a molecular dynamics algorithm, which also confirmed the presence of regions with a low speed of movement, even despite the existence of a cascade motion of components. A serious disadvantage of the proposed mathematical model is that it failed to take into consideration the geometry of components that significantly affect the contact interaction. To obtain the distribution of motion velocities for drum mixers, [14] applied a finite element method in the Euler statement with an elastic model by Mohr-Coulomb, while [15] employed a method for the hydrodynamic construction of the Euler multiphase model. The obtained models make it possible to estimate the distribution of velocity and motion trajectory of similar elements; in practice, the components of a mixture have different physical and geometrical parameters and significantly differ in concentration. Paper [16], in order to describe work of a drum mixer, used a plastic rheological model of a granular medium. They derived dependences of a shear layer's velocity profile on the kinematic, geometric, and rheological parameters of the system. The obtained solutions make it possible to model mixing at tangential (shear) motion of components. Mixing by spreading a mixture of components on the surface of the mixture itself was not studied.

To determine the geometric and operational characteristics for the movement of a material in the cross-section of a drum, [17] used a method of visual analysis applying video recording [17]. The research that employed a given method is not sufficient to build regression dependences that would satisfy the existing diversity of technical solutions for drum mixers.

Our analysis has revealed the presence of theoretical models whose application makes it possible to model the parameters of work of a drum mixer with a smooth inner surface. In this case, the mixing occurs due to displacement at shear movement and the cascade mode of stirring. The main issue when mixing components under such modes of movement is that there are regions with a low velocity of components in the mixture, which greatly increases time costs for obtaining a homogeneous mixture.

One of the ways to improve the efficiency of mixing is the application of a cataracting mode [18]. A given mode of components mixing requires an increase in the angular velocity of rotation. An increase in angular velocity decreases the speed of the mutual movement of a mixture's components. However, such a motion mode results in the detachment of a mixture's components in the upper part of a material's distribution border followed by redistribution of the components in a free flight.

One of the techniques for ensuring an improvement in mixing efficiency and for obtaining a cataracting mode at a smaller angular velocity is to mount blades at the inner surface of a smooth drum. Our analysis of the scientific literature has revealed a lack of theoretical dependences suitable to model the mixing mode of a drum mixer with blades mounted inside it.

Thus, the theoretical and experimental substantiation of the kinematic parameters for the drum-type mixers with blades mounted inside them has not been up to now investigated scientifically well enough and thus has remained an unresolved issue.

\section{The aim and objectives of the study}

The aim of this study is to determine the optimal angular rotation velocity of a drum mixer to enhance the uniformity of mixing the components of mixed fodder.

To accomplish the aim, the following tasks have been set:

- to determine the relationship among the basic structural-technological parameters for a drum mixer with blades 
inside that would make it possible to achieve the maximum distribution of a material's particles of material at the surface of a mixture's segment;

- to experimentally investigate the influence of a drum's angular velocity on the uniformity of mixing feed additives, the concentration of a control component, and the duration of mixing.

\section{Materials and methods to study the parameters of a drum mixer for feed additives}

To determine the optimal angular velocity, we have built a system of equations. This system combines the equation of a falling trajectory of a material's particles, the equation of the line that describes the upper border of a material in the drum, and the equation of circle that describes the inner cross-section of a drum. To determine the radial motion velocity of a particle along the blade of the drum, we have used a solution to the homogeneous differential equation. The numerical value for angular velocity was determined using computer simulation.

To conduct an experimental study into the uniformity of redistribution of components in a mixture of mixed fodder, we designed and manufactured an experimental mixer of the drum type (Fig. 1). The mixer included a chamber, a rectangular frame, a reference frame, and a drive. The mixing chamber had a loading/unloading window with a closed lid. Radial blades were mounted inside the chamber throughout its length and evenly along the perimeter.

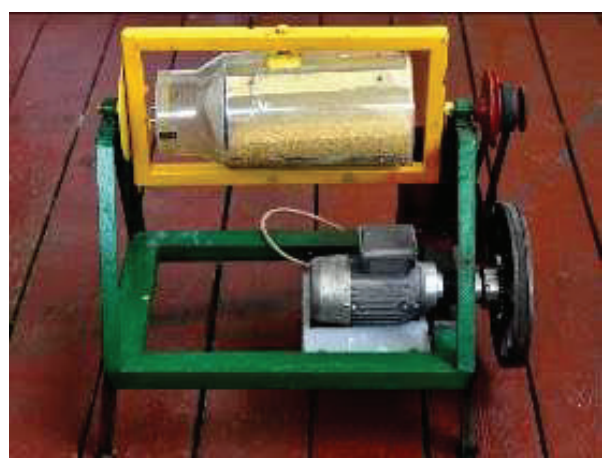

Fig. 1. General view of experimental drum mixer

The used filler to the mixture was composed of shredded grain of barley, wheat, corn, oats, in equal shares, as well as mineral substances (salt, chalk).

A control component used was composed of millet grains painted in red paint with a particle size from 0.5 to $1 \mathrm{~mm}$, which corresponds to the interval of size in the particles of additives to mixed fodder.

Samples from the obtained mixture were selected by a tubular sample-taker directly from the chamber when setting it to the vertical position with the lid removed. The frequency of shaft rotation of the moving frame with the drum was controlled by the electronic tachometer UT372 (China) and registered the duration of each experiment using the stopwatch SOP PR-2A-3-000 «Agat» (Russian Federation). The selected samples were weighted at the laboratory scale AXIS ANJ-100 (Ukraine).

The results obtained from experimental study were treated using the software suit Microsoft Excel 2003.

\section{Results of studying the parameters of a drum mixer}

At drum rotation, a material inside a drum mixer moves with the drum, then it rolls down the surface of the rising material. The material that is captured by a blade when it exits a filled chamber is freely coming off the blade. Mixing takes place within the entire confined space of a chamber, but, depending on the location of a separate particle of a material at a certain time, it has different motion trajectories.

To increase the surface flows in a free space of the chamber it is advisable to set such a width of the blade that would provide for the removal of a material. When a material is not removed completely, it returns to the common flow rather than spreads in a free space of the chamber, which negatively affects the redistribution of components.

At proper operation of a drum mixer, the particles that move radially along the blade and leave it should be evenly distributed at the surface of the mixture. In this case, the final particles that come off the blade should reach the line describing the upper border of a material in the drum at the bottom point of contact with the drum shell (Fig. 2). This condition is defined by the speed of a material coming off the blades, and, respectively, by the drum's angular velocity.

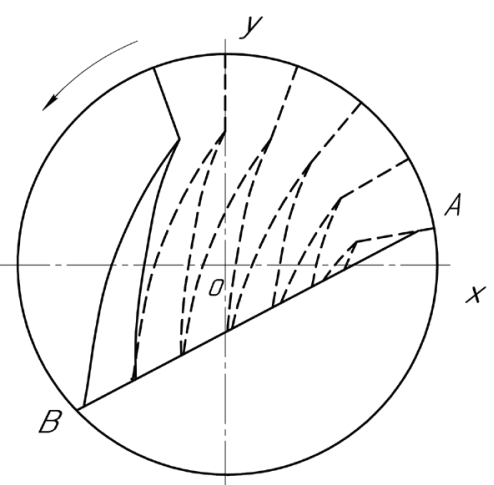

Fig. 2. Example of the optimal distribution of particles that come off the blade in a drum mixer

It is common knowledge that the trajectory of particles' position during fall can be represented by the equation of parabola:

$$
\left\{\begin{array}{l}
x=(R-l) \cos \phi-V_{0} t \cos \gamma_{0} ; \\
y=(R-l) \sin \phi-V_{0} t \sin \gamma_{0}-\frac{g t^{2}}{2},
\end{array}\right.
$$

where $x, y$ are the coordinates of a particle's position during motion along the trajectory, $\mathrm{m} ; l$ is the width of a blade, $\mathrm{m}$; $R$ is the radius of a drum, $\mathrm{m} ; \phi$ is the angle between a blade and the horizontal axis, rad.; $V_{0}$ is the initial absolute velocity of a particle coming off the blade, $\mathrm{m} / \mathrm{s} ; \gamma_{0}$ is the initial inclination angle of a particle's velocity vector to the horizon, rad.; $\mathrm{g}$ is the free fall acceleration, $\mathrm{m} / \mathrm{s}^{2} ; t$ is the current time of a particle's flight, $s$.

The line that describes the upper border of a material in the drum is rather accurately accepted as a chord of the segment with a sectoral angle of $2 \delta$. In this case [19], one can write the equation of the line in the following form:

$$
y=x \operatorname{tg} \alpha-R \frac{\cos \delta}{\cos \alpha}
$$


where $a$ is the inclination angle of the line that limits the upper border of a material in the drum, rad.; $\delta$ is half the sectoral angle of the segment of a material, rad.

Thus, the condition for the full dispersion of particles along the surface of a material is the solution to the following system of equations:

$$
\left\{\begin{array}{l}
y=(R-l) \sin \phi-\frac{(R-l) \cos \phi-x}{\cos \gamma_{0}} \sin \gamma_{0}-\frac{g}{2}\left(\frac{(R-l) \cos \phi-x}{V_{0} \cos \gamma_{0}}\right)^{2} \\
y=x \operatorname{tg} \alpha-R \frac{\cos \delta}{\cos \alpha} \\
R^{2}=x^{2}+y^{2} .
\end{array}\right.
$$

The coordinates for the contact points of the drum's cross section and the line that describes the upper border of a material in the drum can be obtained from a combined solution to the second and third equations of the system, namely:

$$
R^{2}-R^{2} \frac{\cos ^{2} \delta}{\cos ^{2} \alpha}=x^{2}+x^{2} \operatorname{tg}^{2} \alpha-2 x \operatorname{tg} \alpha R \frac{\cos \delta}{\cos \alpha}
$$

or

$$
x^{2}\left(1+\operatorname{tg}^{2} \alpha\right)-2 x \operatorname{tg} \alpha R \frac{\cos \delta}{\cos \alpha}-R^{2}\left(1-\frac{\cos ^{2} \delta}{\cos ^{2} \alpha}\right)=0
$$

hence:

$$
x_{1,2}=R \sin \alpha \cos \delta \pm R \cos \alpha \sin \delta
$$

or

$$
\begin{aligned}
& x_{1}=R \sin \alpha \cos \delta+R \cos \alpha \sin \delta=R \sin (\alpha+\delta), \\
& x_{2}=R \sin \alpha \cos \delta-R \cos \alpha \sin \delta= \\
& =R \sin (\alpha-\delta)=-R \sin (\delta-\alpha) .
\end{aligned}
$$

Accordingly:

$$
\begin{aligned}
& y_{1}^{2}=R^{2}-x_{1}^{2}=R^{2}\left[1-\sin ^{2}(\alpha+\delta)\right]=R^{2} \cos ^{2}(\alpha+\delta), \\
& y_{2}^{2}=R^{2}-x_{2}^{2}=R^{2}\left[1-\sin ^{2}(\alpha-\delta)\right]=R^{2} \cos ^{2}(\alpha-\delta)
\end{aligned}
$$

hence:

$$
\begin{aligned}
& y_{1}=R \cos (\alpha+\delta), \\
& y_{2}=R \cos (\alpha-\delta)=-R \cos (\delta-\alpha) .
\end{aligned}
$$

In a given case, of importance is the coordinate for the contact point of the drum's cross section and the line that describes the upper border of a material in the drum, namely point $B$ (Fig. 2). These coordinates accept values:

$$
\left\{\begin{array}{l}
x_{2}=-R \sin (\delta-\alpha) ; \\
y_{2}=-R \cos (\delta-\alpha) .
\end{array}\right.
$$

Substituting the values obtained in the equation of parabola, we obtain:

$$
\begin{aligned}
& -R \cos (\delta-\alpha)= \\
& =(R-l) \sin \phi-\frac{(R-l) \cos \phi+R \sin (\delta-\alpha)}{\cos \gamma_{0}} \sin \gamma_{0}- \\
& -\frac{g}{2}\left(\frac{(R-l) \cos \phi+R \sin (\delta-\alpha)}{V_{0} \cos \gamma_{0}}\right)^{2} .
\end{aligned}
$$

It is advisable to accept the following as constants (Fig. 3): the width of a blade $l$, the radius of a drum $R$, half the sectoral angle of the segment of a material $\delta$, the angle of inclination of the line describing the upper border of a material in the drum $a$. This makes it possible to determine the angle between the horizontal axis and a blade $\phi=\theta_{0}+\omega t_{P}$, the original inclination angle of a particle's flight velocity vector to the horizon:

$$
\gamma_{0}=\omega t_{P}-\operatorname{arctg} \frac{\omega(R-l)}{V_{R}}
$$

and the initial speed of a particle coming off a blade:

$$
V_{0}=\sqrt{\omega^{2}(R-l)^{2}+V_{R}^{2}} .
$$

The result is:

$$
\begin{aligned}
& -R \cos (\delta-\alpha)=(R-l) \sin \left(\theta_{0}+\omega t\right)- \\
& -\frac{(R-l) \cos \left(\theta_{0}+\omega t\right)+R \sin (\delta-\alpha)}{\cos \left(\omega t-\operatorname{arctg} \frac{\omega r}{V_{R}}(R-l)\right)} \times \\
& \times \sin \left(\omega t-\operatorname{arctg} \frac{\omega(R-l)}{V_{R}}\right)- \\
& -\frac{g}{2}\left(\frac{(R-l) \cos \left(\theta_{0}+\omega t\right)+R \sin (\delta-\alpha)}{\sqrt{\omega^{2}(R-l)^{2}+V_{R}^{2}} \cos \left(\omega t-\operatorname{arctg} \frac{\omega(R-l)}{V_{R}}\right)}\right)^{2},
\end{aligned}
$$

where $\theta_{0}$ is the initial angle of the blade exiting a material, rad.; $\omega$ is the angular velocity of a drum, $\mathrm{rad} / \mathrm{s} ; t_{P}$ is the time of a drum's rotation from a blade exiting the material until its complete unloading, s.

The obtained dependences confirm that the angular velocity of a drum defines the uniform dispersion of particles when they come off a blade.

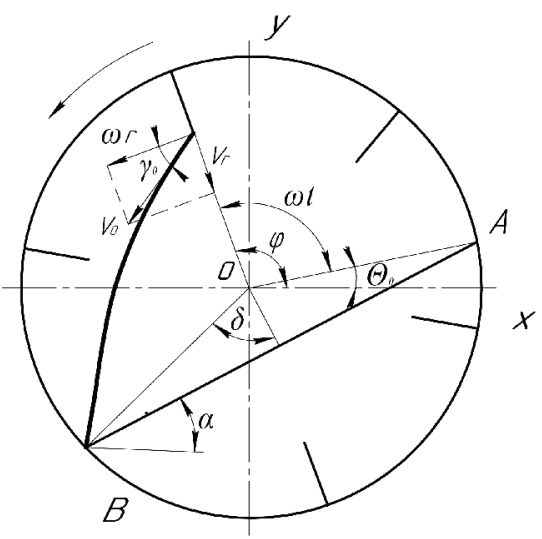

Fig. 3. Cross-section of a drum showing a pattern of the trajectory of a material's particles coming off a blade 
To determine the radial velocity of a particle's motion along the blade of a drum, we shall use a solution to differential equation [20], which takes the form:

$$
\begin{aligned}
& V_{R}=\lambda_{1} C_{1} \exp \left(\lambda_{1} t\right)+\lambda_{2} C_{2} \exp \left(\lambda_{2} t\right)+ \\
& +\frac{g}{\sqrt{4 \omega^{2}+k_{1}^{2}}} \cos \left(\theta_{0}+\operatorname{arctg} \frac{4 f \omega+k_{1}\left(1-f^{2}\right)}{2\left[\omega\left(1-f^{2}\right)-f k_{1}\right]}+\omega t\right) \text {, } \\
& \lambda_{1}=-\left(f \omega+\frac{k_{1}}{2}\right)+\sqrt{\omega^{2}\left(1+f^{2}\right)+\frac{k_{1}^{2}}{4}}, \\
& \lambda_{2}=-\left(f \omega+\frac{k_{1}}{2}\right)-\sqrt{\omega^{2}\left(1+f^{2}\right)+\frac{k_{1}^{2}}{4}}, \\
& C_{1}=\frac{\lambda_{2}}{\lambda_{2}-\lambda_{1}}\left[R-\frac{g}{\omega \sqrt{\left(4 \omega^{2}+k_{1}^{2}\right)}} \sqrt{1+\frac{\omega^{2}}{\lambda_{2}^{2}}} \times\right. \\
& \left.\times \sin \left(\theta_{0}+\operatorname{arctg} \frac{4 f \omega+k_{1}\left(1-f^{2}\right)}{2\left[\omega\left(1-f^{2}\right)-f k_{1}\right]}-\operatorname{arctg} \frac{\omega}{\lambda_{2}}\right)\right], \\
& C_{2}=\frac{\lambda_{1}}{\lambda_{2}-\lambda_{1}}\left[\frac{g}{\omega \sqrt{\left(4 \omega^{2}+k_{1}^{2}\right)}} \sqrt{1+\frac{\omega^{2}}{\lambda_{1}^{2}}} \times\right. \\
& \left.\times \sin \left(\theta_{0}+\operatorname{arctg} \frac{4 f \omega+k_{1}\left(1-f^{2}\right)}{2\left[\omega\left(1-f^{2}\right)-f k_{1}\right]}-\operatorname{arctg} \frac{\omega}{\lambda_{1}}\right)-R\right] \text {, }
\end{aligned}
$$

where $\lambda_{1}, \lambda_{2}$ are the roots of a characteristic equation, $\mathrm{s}^{-1}$; $k_{1}$ is the coefficient of proportionality at laminar flow of air around a particle, $\mathrm{s}^{-1} ; f$ is the friction coefficient of a particle against a material of the blade, relative units.

The coordinates for a particle's position at a time point when it comes off the blade, according to equation (6), are defined by its radial motion velocity along the blade of a drum at a time point it comes off the blade $V_{R}(R-l)$. This allows one to determine the absolute velocity of particle $V_{o}$ and the initial inclination angle of a particle's flight absolute velocity vector to the horizon $\gamma_{0}$. Fig. 4 shows a graphical solution to the equations in a system of equations that includes equations (6) and (7).

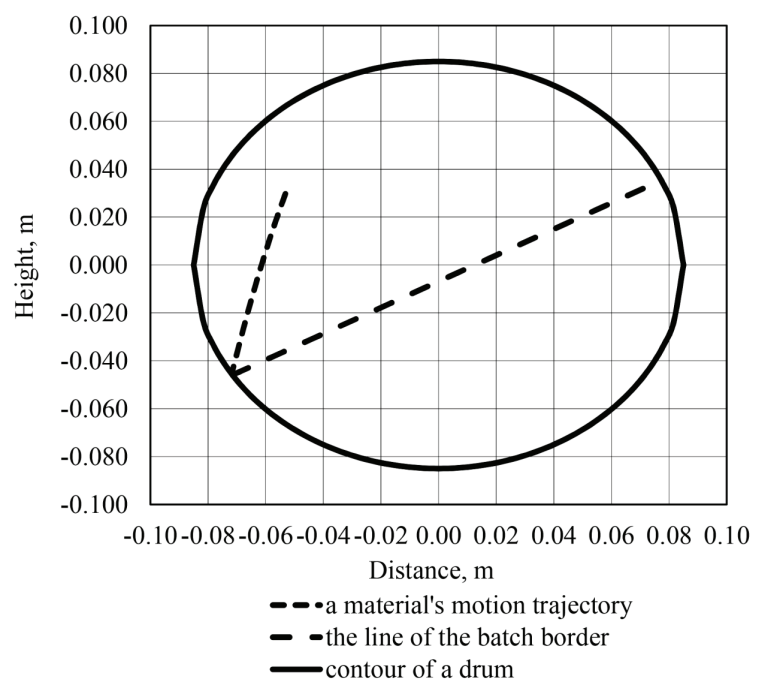

Fig. 4. Illustration of a joint graphic solution to equations (6) and (7) that ensures that a material's particles that come off a blade travel to the extreme left point at a batch border
This solution was derived from computer simulation for the following conditions: the coefficient of filling a chamber with a radial arrangement of blades is 0.5 , the radius of the drum is $0.17 \mathrm{~m}$.

It was established that a drum mixer with blades with a width of $25 \mathrm{~mm}$ ensures the scattering a material's particles at the surface of a working segment at the drum's angular velocity $9.69 \mathrm{rad} / \mathrm{s}$. In this case, the angle of a blade's turn from the horizontal axis to exiting a mixture was $30^{\circ}$.

\section{Results of experimental study into the operational parameters of a drum mixer}

To confirm the results from theoretical calculations, we have experimentally investigated the effect of angular velocity on the uniformity of mixing in a drum mixer.

To establish the magnitude of acting factors, we performed preliminary clarifying experiments. The process of distribution of each component in the overall mass of a material at mixing takes place in the function of time, which is why prolonging the duration of the process leads to the increased uniformity of a mixture. The dependence of uniformity on mixing duration in the time interval from $60 \mathrm{~s}$ to $420 \mathrm{~s}$ is shown in Fig. 5.

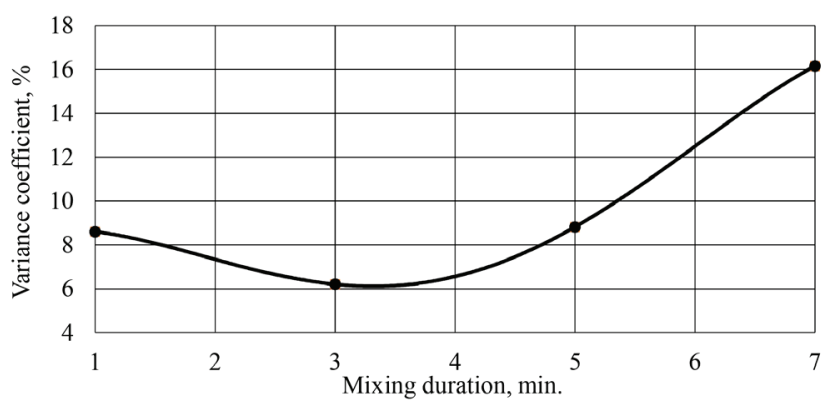

Fig. 5. Influence of mixing duration on the coefficient of variation of the distribution of a control component in a mixture at the chamber's fill factor $k=0.5$, rotation frequency $n=90 \mathrm{rev} / \mathrm{min}$ and the dose of a control component $a=3 \%$

As shown by a given dependence, after spending $60 \mathrm{~s}$ in the chamber, the uniformity was $91.7 \%$, and over subsequent $60 \mathrm{~s}$ increased to $92.8 \%$, that is, it approached the lower limit of zootechnical requirements.

Next, there is an improvement in the uniformity indicator. Thus, when the period lasted for $180 \mathrm{~s}$ the uniformity increased to $94.1 \%$. The shape of the curve indicates a deterioration in the quality of mixing with an increase of time, due to the phenomenon of segregation (separation of small and heavy particles).

Thus, the duration of mixing that meets zootechnical requirements in terms of quality of the obtained feed additives for the uniformity of components distribution throughout the total mass of a material ranges from 180 to $240 \mathrm{~s}$. This magnitude was adopted for the further research into the process of mixing.

Determining an optimal magnitude for the introduced dose of a control component (Fig. 6) points to the complexity of distribution of small doses throughout the total mass of a material, which confirms the need for a stagewise mixing of components in the manufacture of feed mixtures. 


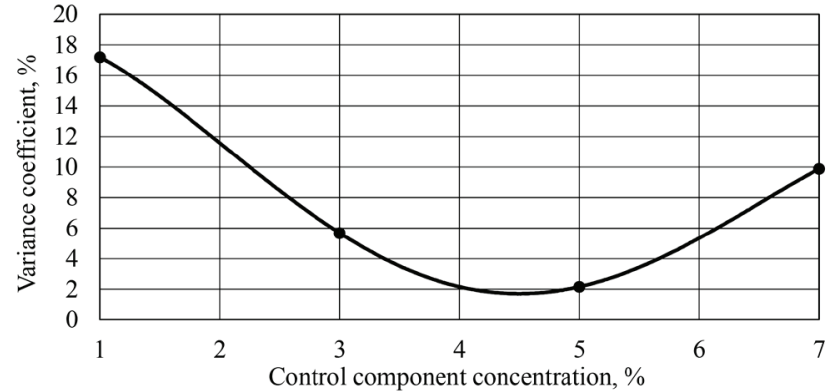

Fig. 6. Influence of the concentration of a control component of mixing on the variation coefficient of the distribution of a control component in a mixture at the chamber's fill factor $k=0.5$, rotation frequency $n=90 \mathrm{rpm}$, and mixing duration $t=180 \mathrm{~s}$

Increasing the concentration of a control component to $a=5 \%$ leads to a certain growth in the mixing uniformity indicator.

In the course of an experimental research into the influence of angular velocity on the uniformity of mixing in a drum mixer other acting factors were registered for the following magnitudes: mixing duration $t=180 \mathrm{~s}$; the chamber's fill factor $k=0.5$. Measurements were carried out with an amount of the introduced control component of $a=5 \%$ of the total mass of a material in a chamber.

Over the interval of drum rotation frequency from $\omega=$ $=4.18 \mathrm{rad} / \mathrm{s}(n=40 \mathrm{rpm})$ to $\omega=12.6 \mathrm{rad} / \mathrm{s}(n=120 \mathrm{rpm})$ there is a change in the variation coefficient of the obtained mixture, whose functional dependence is shown in Fig. 7.

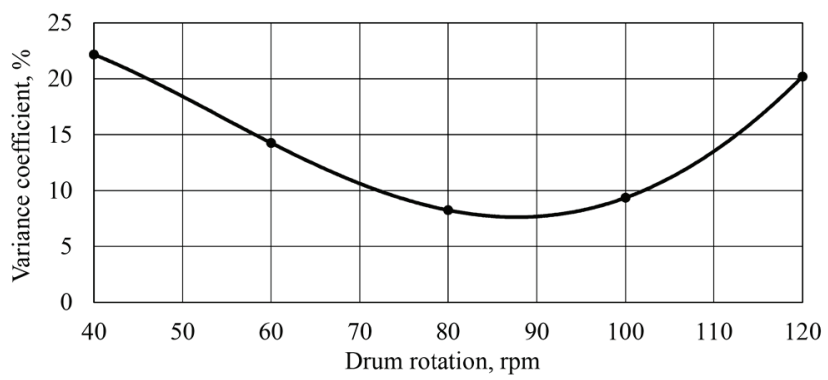

Fig. 7. Influence of drum rotation on the variance coefficient of the distribution of a control component in a mixture at the chamber's fill factor $k=0.5$, mixing duration $t=180 \mathrm{~s}$ and a dose of control component $a=5 \%$

The above diagram shows that an increase in rotation frequency leads to a more uniform distribution of a control component throughout the total mass of the material. Variance coefficient decreases at an increase in the drum rotation to $90 \mathrm{rpm}(9.42 \mathrm{rad} / \mathrm{s})$. Given such a rotation frequency, it is possible to achieve the uniformity of the resulting mixture at the level of $92-93 \%$.

Next, the dependence demonstrates growth, showing a rapid deterioration in the quality of mixing. A given character of the dependence is explained by the increasing centrifugal force that presses a material to the walls of the drum and leads to a decrease in active flows in the surface regions of the chamber (Fig. 8).

Thus, the recommended rotation frequency of the drum in a mixer was $85-90 \mathrm{rpm}$, which corresponds to the drum's angular velocity from 8.89 to $9.42 \mathrm{rad} / \mathrm{s}$.

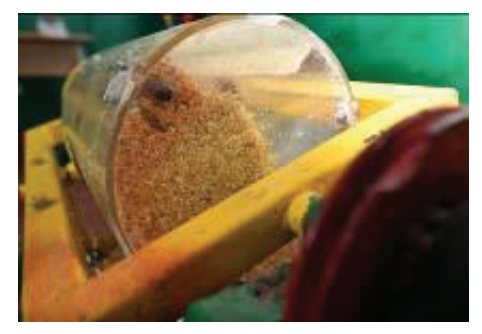

$a$
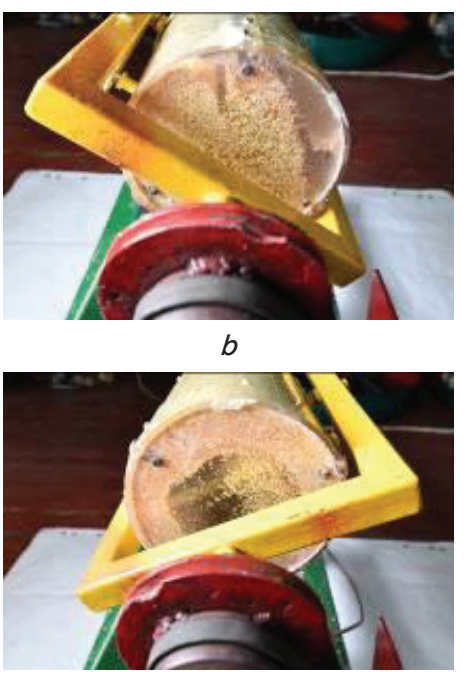

$c$

Fig. 8. Motion modes of a mass of mixed fodder in a drum mixer: $a$ - motion with a fall; $b$ - circulating motion; $c$ - closed motion mode

The maximum discrepancy between the theoretical and experimental data is about $9 \%$. The obtained results make it possible to argue about the possibility of applying dependence (6) for the implementation of theoretical modelling of operational parameters for drum mixers.

\section{Discussion of results of studying the parameters of a drum mixer for feed additives}

Application of drum mixers makes it possible to obtain feed mixtures of high uniformity, thus eliminating the phenomenon of segregation and formation of «dead» zones. The presence of radial blades inside the chamber distributes a mixing body and increases the surface flows, thereby improving the redistribution of a material and the quality of mixing.

The operational process of a drum mixer is divided into several separate and, at the same time, simultaneous elementary processes. First, it is the stirring of separate adjacent volumes of a material by contact mixing when the layers of a material slide. Second, this is the redistribution of particles between the adjacent amounts of a material though the penetration of particles (diffusion) via the border section of the volumes of a material. An integral part of the operational process of a drum mixer is the concentration (segregation) of particles of equal mass under the action of gravity forces. It is obvious that the contact mixing and diffusion penetration of particles contribute to the distribution of an added component throughout the total mass of the material. In turn, the concentration of particles of the same mass downgrades uniformity. However, for drum mixers, the impact of segregation is mostly neutralized owing to the return of heavy and small 
particles from the added components from the lower to the upper layers of a mixed material due to rotation.

By analyzing the movement of a material's flows in a drum mixer, which was additionally equipped with radial blades, we have substantiated, based on the laws of mechanics, conditions for the uniform distribution of added components in a mixture (Fig. 2). Achieving a uniform distribution of the material that comes off a drum's blade over the entire width of the batch makes it possible to maximally implement the benefits of a cataracting mode at smaller angular velocity. A system of equations has been built (3), solving which makes it possible to determine the angular velocity of drum rotation, to ensure the distribution of the material carried over by the blades over the width of the batch of the dynamic angle of material at rest (Fig. 3). Solving a system of equations (3) makes it possible to simulate the optimal operation mode for mixers based on its structural parameters and the properties of a mixture's materials.

The result of simulation based on the structural parameters of an existing drum mixer with installed blades is the derived optimal value for the angular velocity of drum rotation, which meets zootechnical requirements for mixing materials. The performed experimental study on determining the influence of angular velocity of a drum mixer's rotation on the quality of mixing components has shown a rather good correlation between the calculated and experimentally defined angular velocity.

Application of the constructed mathematical model makes it possible to determine an optimal angular rotation velocity of the mixer when changing the structural and technological parameters of the mixer. However, the resulting discrepancy between the estimated and theoretical angular velocities indicates the need for introducing to the mathematical model the parameters that would describe a geometric shape and the properties of a mixture's components. The results obtained will make it possible to more accurately determine the operation modes of a mixer depending on the properties of mixed materials. In addition, an important field for the further research is the construction of a mathematical model for the distribution of longitudinal movements of a material caused by the inclination angle of the rotation axis of a drum mixer.

\section{Conclusions}

1. We have built a system of equations that describe operation of a drum mixer with installed blades while providing for the effective mixing of a mixture's components. The derived theoretical dependences have made it possible to model the scattering of particles of a material depending on the angular velocity and structural parameters of a drum mixer. It was established based on the structural parameters of an actual drum mixer that the best distribution of a mixture's components could be achieved at the drum's angular velocity $9.69 \mathrm{rad} / \mathrm{s}$.

2. Our experimental study has shown that it is possible to obtain the best uniformity in the distribution of a material in the mixture when the mixing duration is close to $180 \mathrm{~s}$ and at the concentration of a control component of $5 \%$. The drum's rotation angular velocity from 8.89 to $9.42 \mathrm{rad} / \mathrm{s}$ makes it possible to obtain the uniformity of a mixture of $92.5-93 \%$, thereby meeting acting zootechnical requirements for all types of mixed fodder. The maximum deviation of the theoretically defined angular velocity of the drum mixer's rotation from that determined experimentally was about $9 \%$.

\section{References}

1. Proizvodstvo kombikormov v usloviyah lichnyh podsobnyh i fermerskih hozyaystv: monografiya / Krasnov I. N., Filin V. M., Globin A. N., Ladygin E. A. Zernograd: FGBOU VPO ACHGAA, 2014. 228 p.

2. Dudka S., Toshynskiy V. Research of granulation and drying process in technology of fertilizer «Superagro N: P 10:40» // Eastern-European Journal of Enterprise Technologies. 2012. Vol. 4, Issue 6 (58). P. 7-10. URL: http://journals.uran.ua/eejet/article/view/5583/5023

3. Modeling of mechanical treatment of napiform onion to determine the rational parameters of its cleaning / Tereshkin O., Horielkov D., Dmytrevskyi D., Chervonyi V. // Eastern-European Journal of Enterprise Technologies. 2016. Vol. 6, Issue 11 (84). P. 30-39. doi: https://doi.org/10.15587/1729-4061.2016.86472

4. Makarov Yu. I., Sal'nikova G. D. Osnovnye tendencii sovershenstvovaniya otechestvennogo, oborudovaniya dlya smeshivaniya sypuchih materialov // Neftyanoe i himicheskoe mashinostroenie. 1993. Issue 10. P. 5-8.

5. Lu G., Third J. R., Müller C. R. Discrete element models for non-spherical particle systems: From theoretical developments to applications // Chemical Engineering Science. 2015. Vol. 127. P. 425-465. doi: https://doi.org/10.1016/j.ces.2014.11.050

6. Liu P. Y., Yang R. Y., Yu A. B. DEM study of the transverse mixing of wet particles in rotating drums // Chemical Engineering Science. 2013. Vol. 86. P. 99-107. doi: https://doi.org/10.1016/j.ces.2012.06.015

7. Norouzi H. R., Zarghami R., Mostoufi N. Insights into the granular flow in rotating drums // Chemical Engineering Research and Design. 2015. Vol. 102. P. 12-25. doi: https://doi.org/10.1016/j.cherd.2015.06.010

8. Numerical study of mixing of binary-sized particles in rotating tumblers on the effects of end-walls and size ratios / Zhang Z., Gui N., Ge L., Li Z. // Powder Technology. 2017. Vol. 314. P. 164-174. doi: https://doi.org/10.1016/j.powtec.2016.09.072

9. Ma H., Zhao Y. Modelling of the flow of ellipsoidal particles in a horizontal rotating drum based on DEM simulation // Chemical Engineering Science. 2017. Vol. 172. P. 636-651. doi: https://doi.org/10.1016/j.ces.2017.07.017

10. Numerical simulation and analysis of mixing of polygonal particles in 2D rotating drums by SIPHPM method / Gui N., Yang X., Tu J., Jiang S. // Powder Technology. 2017. Vol. 318. P. 248-262. doi: https://doi.org/10.1016/j.powtec.2017.06.007

11. Numerical investigation of granular flow similarity in rotating drums / Qi H., Xu J., Zhou G., Chen F., Ge W., Li J. // Particuology. 2015. Vol. 22. P. 119-127. doi: https://doi.org/10.1016/j.partic.2014.10.012

12. Gan J. Q., Zhou Z. Y., Yu A. B. A GPU-based DEM approach for modelling of particulate systems // Powder Technology. 2016. Vol. 301. P. 1172-1182. doi: https://doi.org/10.1016/j.powtec.2016.07.072

13. Molecular dynamics simulation and continuum modelling of granular surface flow in rotating drums / Li S., Yao Q., Chen B., Zhang X., Ding Y. L. // Chinese Science Bulletin. 2007. Vol. 52, Issue 5. P. 692-700. doi: https://doi.org/10.1007/s11434-007-0069-4 
14. Zheng Q. J., Yu A. B. Modelling the granular flow in a rotating drum by the Eulerian finite element method // Powder Technology. 2015. Vol. 286. P. 361-370. doi: https://doi.org/10.1016/j.powtec.2015.08.025

15. Studying the solids and fluid flow behavior in rotary drums based on a multiphase CFD model / Delele M. A., Weigler F., Franke G., Mellmann J. // Powder Technology. 2016. Vol. 292. P. 260-271. doi: https://doi.org/10.1016/j.powtec.2016.01.026

16. Naumenko Y., Sivko V. The rotating chamber granular fill shear layer flow simulation // Eastern-European Journal of Enterprise Technologies. 2017. Vol. 4, Issue 7 (88). P. 57-64. doi: https://doi.org/10.15587/1729-4061.2017.107242

17. Sheng L.-T., Chang W.-C., Hsiau S.-S. Influence of particle surface roughness on creeping granular motion // Physical Review E. 2016. Vol. 94, Issue 1. doi: https://doi.org/10.1103/physreve.94.012903

18. Chou H.-T., Lee C.-F. Cross-sectional and axial flow characteristics of dry granular material in rotating drums // Granular Matter. 2009. Vol. 11, Issue 1. P. 13-32. doi: https://doi.org/10.1007/s10035-008-0118-y

19. Makevnin M. P., Pershin V. F., Sviridov M. M. Raschet vremeni padeniya chastic sypuchego materiala v barabannyh sushilkah s lopastnoy nasadkoy // Himicheskoe i neftyanoe mashinostroenie. 1984. Issue 9. P. 31-32.

20. Golub G., Pavlenko S., Kukharets S. Analytical research into the motion of organic mixture components during formation of compost clamps // Eastern-European Journal of Enterprise Technologies. 2017. Vol. 3, Issue 1 (87). P. 30-35. doi: https://doi.org/ 10.15587/1729-4061.2017.101097

\begin{tabular}{|c|}
\hline 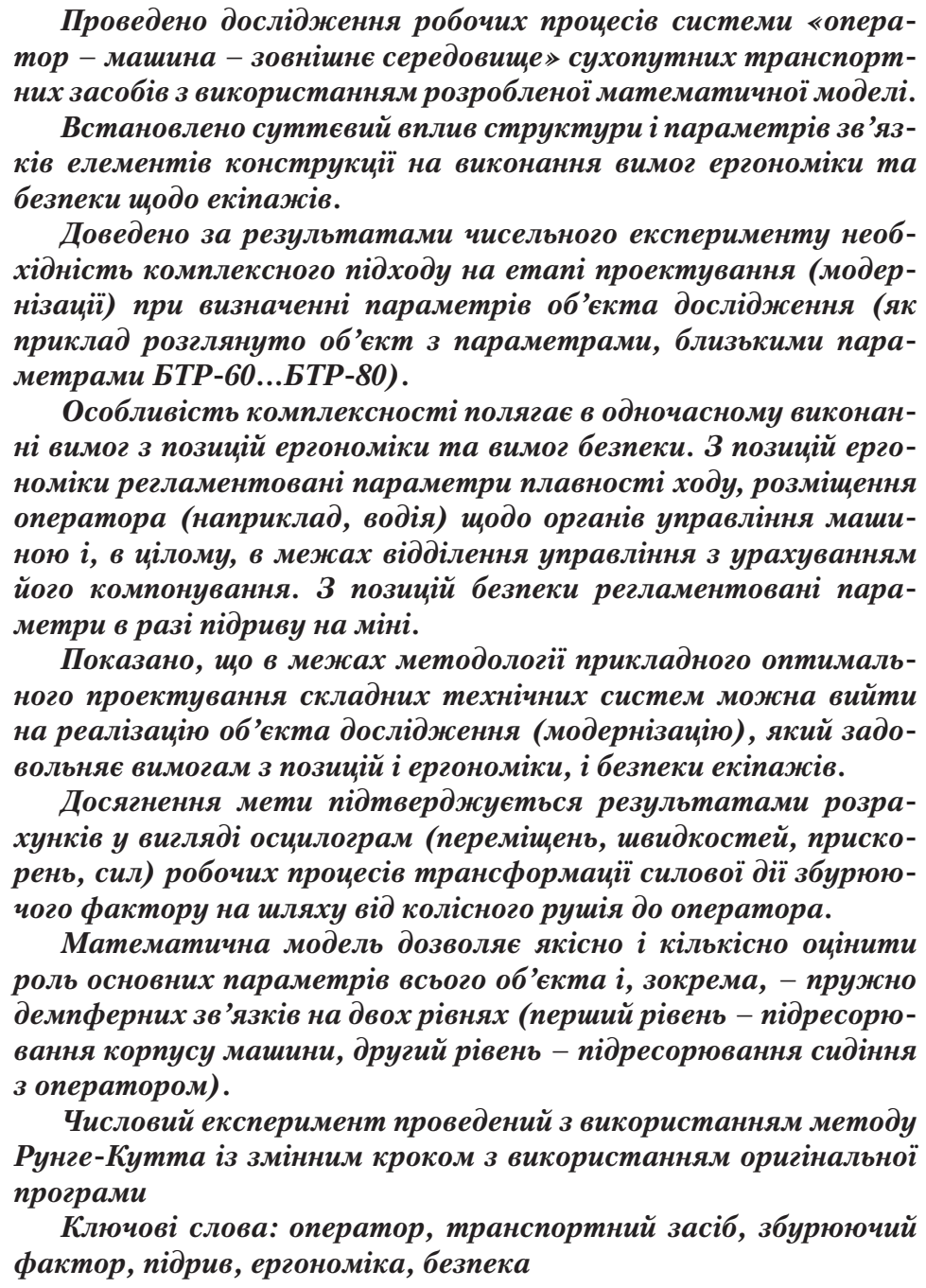 \\
\hline
\end{tabular}

\title{
DETERMINING THE PARAMETERS FOR CONNECTIONS AMONG THE ELEMENTS OF DESIGN OF VEHICLES IN TERMS OF ERGONOMICS AND CREW SAFETY
}

\author{
V. P is a rev \\ Doctor of Technical Sciences, Professor \\ Department of Armored Vehicles \\ National Academy of \\ National Guard of Ukraine \\ Zakhysnykiv Ukrainy sq., 3 , \\ Kharkiv, Ukraine, 61001 \\ E-mail: valerijpisarev7@gmail.com
}

\section{Introduction}

At present, construction (modernization) of wheeled and tracked vehicles, especially for military purposes, faces a contradiction in the requirements for ergonomics, require- ments for safety of crew members (troops). According to the requirements for ergonomics, the parameters for fluctuations and vibrations, resulting from the interaction with a bearing surface, on the one hand, and the implementation of working operations of an engine and the transmission, on the other 